\title{
Economic sanctions, trade and economic relations between two leaders: a case of Russia and France
}

\author{
Olga Elfimova \\ University of Tyumen \\ Volodarskogo Street 6, 625003 Tyumen \\ Russian Federation \\ e-mail: o.s.elfimova@utmn.ru \\ Valeriya Vysotckaya \\ University of Tyumen \\ Volodarskogo Street 6, 625003 Tyumen \\ Russian Federation \\ e-mail: vyvaleriya@yandex.ru \\ Tatyana Luzina \\ University of Tyumen \\ Volodarskogo Street 6, 625003 Tyumen \\ Russian Federation \\ e-mail: goryachkina_taty@mail.ru
}

\begin{abstract}
This paper examines the trade relations and trade flows between Russia and France. Both countries represent truly leading powers, one in BRICS and the other one in the European Union. Moreover, it also tackles the economic relations between these two leaders of international trade hindered by the recent political and economic problems.

In recent years, under the influence of sanctions imposed by some Western governments against Russia, bilateral trade and investment cooperation between the two countries have undergone a number of important changes. Our paper analyses the trade turnover between the countries for several years and reveals the main changes in its structure. In spite of the overall atmosphere of restriction and sanctions, we have identified some promising areas for further economic cooperation.
\end{abstract}

\section{Introduction}

In modern conditions, economic sanctions have turned into a frequently used instrument of foreign policy. Of course, this instrument disrupts international trade and makes the conditions for international economic relations harder and more complicated (Brodzicki 2016; Cieślik et al. 2016; Danshina and Britchenko 2017; NiñoAmézquita et al. 2017; Kubeš and Rančák 2018; or Zemguliene and Valukonis 2018). International instruments do not have a precise and exhaustive definition of the economic sanctions. The United Nations Charter also has no concept of "the economic sanctions but refers to "complete or partial interruption of economic relations and of rail, sea, air, postal, telegraphic, radio and other means of communication" (United Nations 2018). Economic sanctions can be considered as deliberate, initiated by the government the suspension of international intergovernmental organizations (the threat of suspension) established foreign trade relations. Restrictions on international trade, financial transactions and the movement of people are the most common forms of sanctions.

A wide range of scientific papers is devoted to the issues of rational use and effectiveness of sanctions. Hafbaujer and co-authors (Hafbaujer et al. 2007) argue that only 34\% of all cases of application of international sanctions in the course of the $20^{\text {th }}$ century can be considered successful. MakGi (2014) used the results of his study to confirm that the cost of imposing sanctions is higher than the potential economic and political benefits. In the foreign and Russian literature are considered problematic issues to supplement the classification of sanctions, refinement of the tiers (Dmitrieva 2015; or Russell 2016) and the so-called "waves" (Crozet et al. 2016) including the example of the anti-Russian sanctions regime. Some experts turn to the global effects of international sanctions - primarily for world trade (Crozet et al. 2016).

European sanctions or, more accurately, the restrictive measures applied to the Russian Federation in 2014, were connected with Ukrainian and Crimean events 2013-2014 directed on political issues between Russia, Ukraine, and the European Union. The Russian Federation responded with so-called "counter-sanctions". 
The European Union remains the historical and economic partner of Russia. Moreover, there is a long history of cooperation in energy, namely supplying the EU countries with Russian oil and gas at affordable prices that became the cornerstone of the EU energy strategy (see e.g. Gonda 2013; Lisin et al. 2015; 2016).

The Russian Federation is also one of the top five trading partners of the EU (Kastakova 2016). However, relationships between this two important trade and economic partners has deteriorated significantly since the imposition of the sanctions. The losses of the Russian economy from the sanctions, according to a number of experts, during 2014-2017makes about $\$ 170$ billion. At the official level, the amount of actual losses is estimated at \$20-25 billion. The losses of the European economy today is difficult to estimate. According to various estimates, it ranges from $\$ 10$ to $\$ 100$ billion. Trade and economic relations between Russia and France were not an exception. Although France is one of the countries that perceive sanctions as a temporary measure, and more recently has been talking about their weakening (Kuznetsov et al. 2016).

\section{Foreign trade relations between Russia and France}

The development of economic relations between Russia and France was determined both by internal development strategy and by foreign policy. Trade and economic relations between France and Russia originate from the time of Yaroslav the Wise (Yaroslav Mudryj) when a political marriage was concluded between his daughter Anna and the King of France Henry I. The relations have more than two centuries of history, but their modern foundation was laid in February 1992 by the signing an agreement on trade and economic cooperation of Russia and France. The retrospective evaluation of the development of foreign trade relations allowed:

- traditional trading partnerships. France and Russia have been supporting bilateral economic ties for most of the century and they have gained substantial practical experience.

- definite limitation. France and Russia are developing trade and economic relations within certain limits. France supplies industrial products to the world market which accounted for $79 \%$ in 2014, Russia's supply of fuel was $71 \%$.

- the quality of trade and economic relations depends on the state of political relations between Paris and Moscow.

All these features have not lost relevance today (Kuznetsov et al. 2016). France is the country that introduced a minimum of economic sanctions. It officially announced the suspension of the delivery to Russia of the first of the two ordered earlier Mistral-class helicopter carriers, Vladivostok, as well as the suspension of most of the military cooperation with Russia, including the exchange of visits and joint military training. Later it turned out that shipments of helicopter carriers were not canceled, and the completion of projects would take place occurs with a slight delay (Minchicova and Baryshnikov 2014).

Let us consider how this political situation in the world affected the trade and economic relations between Russia and France. The sanctions affected the trade turnover between the two countries negatively (Figure 1). The total trade turnover of Russia and France decreased by $36 \%$ (or almost $\$ 7$ billion) in 2015, compared to the indicator of 2014 , and amounted to about $\$ 11.6$ billion. The main role in the deterioration of the trade indicators is the decline in the supply of French products to Russia, when imports from France fell by more than half.

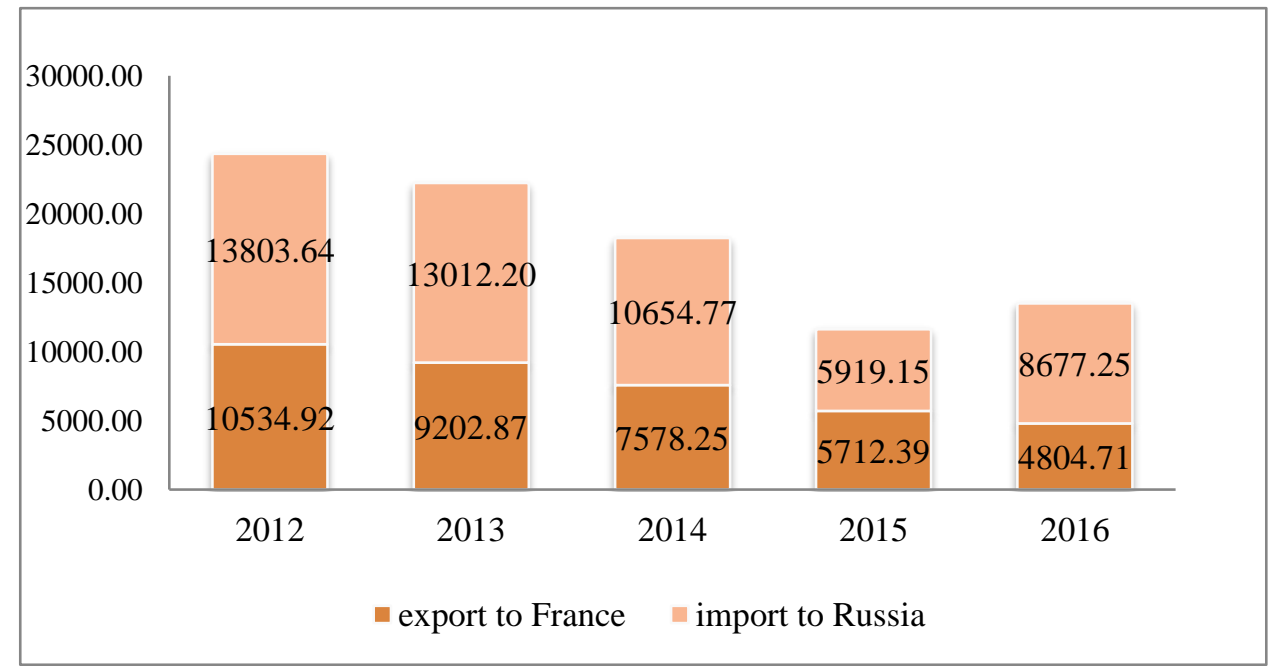

Fig 1. Dynamics of trade turnover between Russia and France 2012-2016 (million US dollars) Source: Federal Customs Service of Russia (2018) 
In 2016, positive trends were set, the total trade turnover increased by $16 \%$ compared to 2015 . This was due to the direct growth of imports from France by $47 \%$. Russian exports to France fell throughout the period from 2012 to 2016 . One of the reasons is the decline in the price of mineral fuel, which is the basis of Russian exports.

The sectoral structure of Russian-French trade has remained stable for the past five years. The basis of French exports consist of only 4 groups of goods, the main of which are nuclear reactors, boilers, equipment and mechanical devices. The results of 2015 and 2016 show that the sanctions began to transform the ratio of the main groups of goods, and they caused a sharp drop in these groups. In particular, in 2015 the volume of imports of pharmaceutical products fell by 1.8 times in comparison with 2014, essential oils and resinoids; perfumes, cosmetic products fell by 1.4 times, nuclear reactors, boilers, equipment and mechanical devices fell by 1.7 times (see Table 1 and Figure 2).

Table 1. Dynamics of the main imported goods from France to Russia (thousand US dollars)

\begin{tabular}{|l|c|c|c|c|c|}
\hline \multicolumn{1}{|c|}{ Name of goods group } & 2012 & 2013 & 2014 & 2015 & 2016 \\
\hline Pharmaceutical products & 1360292 & 1410290 & 1244024 & 699377 & 811923 \\
\hline $\begin{array}{l}\text { Essential oils and resinoids; } \\
\text { perfumes, cosmetic products }\end{array}$ & 951786 & 1065630 & 951781 & 683345 & 648469 \\
\hline $\begin{array}{l}\text { Nuclear reactors, boilers, } \\
\text { equipment and mechanical devices }\end{array}$ & 1958839 & 1891879 & 1632796 & 959519 & 948130 \\
\hline Electric machines and equipment & 1280954 & 1116136 & 858168 & 548189 & 730854 \\
\hline
\end{tabular}

Source: Federal Customs Service of Russia (2018)

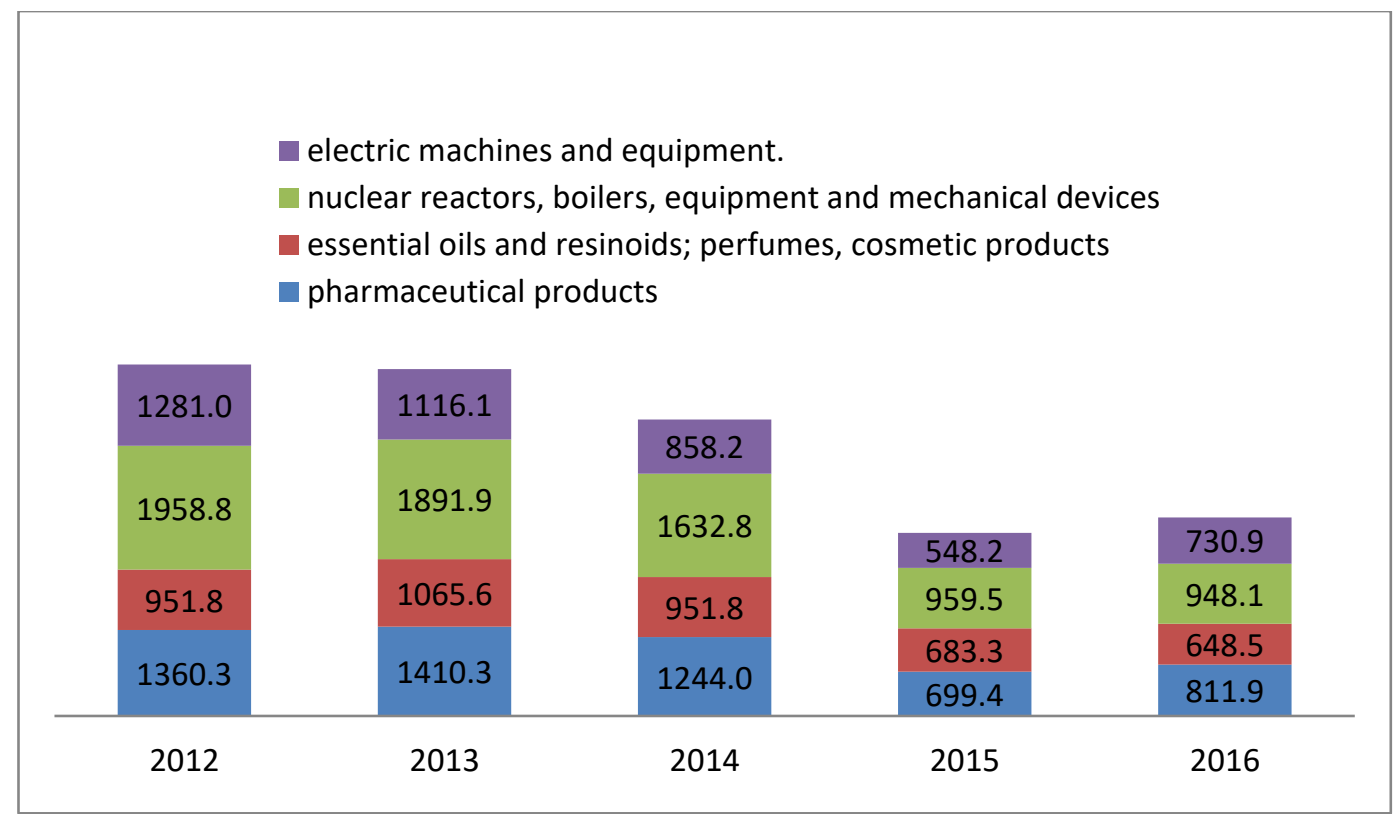

Fig 2. Dynamics of the main imported goods from France to Russia (million US dollars)

Source: Federal Customs Service of Russia (2018)

The embargo imposed by the Russian Federation affected the sectoral structure of Russian-French trade as early as 2014. Throughout 2014, the French exports of embargoed goods year decreased by $41.5 \%$ in value. Supplies of pork fell by $95.3 \%$, cheese and curd supplies fell by $46.4 \%$, milk and cream by $53.9 \%$. As a result, the share of food products and agricultural raw materials in French supplies to Russia is approaching 8\% now, although even 5 years ago it exceeded $12 \%$.

In 2016, the basis of Russian exports to France were 4 groups of goods, the main of which remains mineral fuel. At the same time, the share of fuel is gradually decreasing, the volume of imports of mineral fuel in 2016 fell by almost 1.7 times compared with 2014, in turn, the volume of export of reactors and nuclear boilers increased almost 1.7 times. Trends for the rest of the goods groups can be seen in the Figure 3 . 


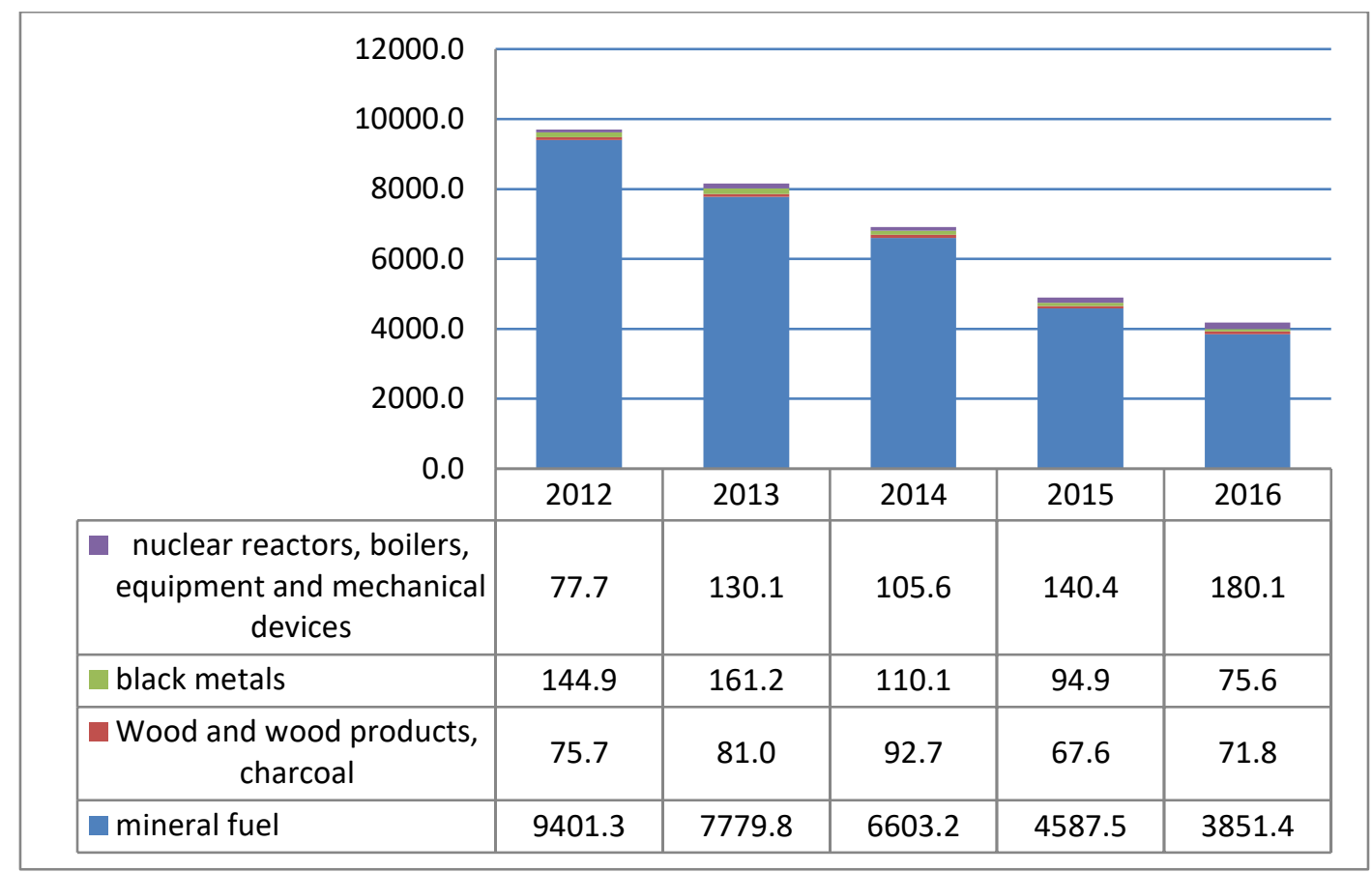

Fig 3. Dynamics of the main exported goods from Russia to France (million US dollars) Source: Federal Customs Service of Russia (2018)

The role of the Russian Federation in French exports has been steadily declining for 4 years. In 2015, the positions of the Russian Federation weakened not only in exports but also in imports, falling below the figures for 2009 (1.5\% and 2.3\%, respectively). In the French exports, Russia was preceded by smaller European partners such as Sweden, Poland, as well as Japan. As a result, Russia took 17th place, which was not observed in the last decade. The Russian share in French imports has been declining for 4 years, an average of $11 \%$ annually, including the drop in raw material prices. Therefore, Russia went beyond the top ten partners, losing to Poland and Japan (Table 2).

Table 2. Positions of Russia and France in each other's foreign trade

\begin{tabular}{|l|c|c|c|c|}
\hline \multicolumn{1}{|c|}{ Index } & 2012 & 2013 & 2014 & 2015 \\
\hline $\begin{array}{l}\text { Share of the Russian Federation in the } \\
\text { export of France }\end{array}$ & $2,47 \%$ & $2,29 \%$ & $1,88 \%$ & $1,20 \%$ \\
\hline $\begin{array}{l}\text { Share of the Russian Federation in the } \\
\text { import of France }\end{array}$ & $1,58 \%$ & $1,37 \%$ & $1,13 \%$ & $1,02 \%$ \\
\hline $\begin{array}{l}\text { Share of France in the export of the } \\
\text { Russian Federation }\end{array}$ & $2,01 \%$ & $1,75 \%$ & $1,52 \%$ & $1,66 \%$ \\
\hline $\begin{array}{l}\text { Share of France in the import of the } \\
\text { Russian Federation }\end{array}$ & $4,35 \%$ & $4,13 \%$ & $3,71 \%$ & $3,24 \%$ \\
\hline
\end{tabular}

\section{Source: Own results}

France's position in Russia's foreign trade is more stable. France has retained its place at the end of the second ten Russian export partners, despite the decline in its share in exports. In the period from 2012 to 2014 , the share of France in the Russian import is falling steadily, with the sharp drop of 10, $2 \%$ and 12.7 in 2014 and 2015 respectively. Despite this, France remains among the ten major trade partners of the Russian Federation for imports.

\section{Investment cooperation}

France is one of the key European investors in the Russian economy, being on the 6th place ahead of Germany and the USA (in 2013, Russia received 10.3 billion dollars of French investments, according to the French side data they were 11.5 billion euros). France is aimed at expanding its business in Russia. In 2014, about 250 million US dollars were invested in the development of the retailer Auchan. Today there are about 1,200 French companies in Russia, about 7,000 companies produce foreign trade operations with Russian partners. 
According to the president of the Franco-Russian Chamber of Commerce Emanuel Kide, in 2015, French investments in Russia were to amount to several billion dollars (Ria News 2015). However, Russian statistics did not confirm this fact. From 2011 to 2014 Direct French investment in the Russian Federation grew, but in 2015 there was a sharp drop of $24 \%$ in the investment flow. The year of 2015 was a failure with Russian investments falling more than sevenfold (see Table 3 and Figure 4).

The main reason for such negative results in 2015 can be attributed to the lack of funding from the banking sector, which was sanctioned. Foreign banks almost do not allocate funds for Russia based projects of French companies, and Russian banks offer very expensive loans in comparison with European ones.

Russia is not among the main investor countries in the French economy, among which the United States and Germany play the most important role, accounting for about 33\% of investment projects in 2013-2014[10]. Russia held the 16 th place in 2014 , providing $1.2 \%$ of projects and $1.3 \%$ of employees.

Table 3. Mutual flows of foreign direct investment (FDI) in Russia and France (million US dollars)

\begin{tabular}{|l|c|c|c|c|c|}
\hline \multicolumn{1}{|c|}{ Index } & 2011 & 2012 & 2013 & 2014 & 2015 \\
\hline FDI of France to the Russian Federation & 1107 & 1232 & 2121 & 2224 & 1686 \\
\hline FDI of the Russian Federation to France & 656 & 1430 & 449 & 523 & 74 \\
\hline
\end{tabular}

Source: Own results

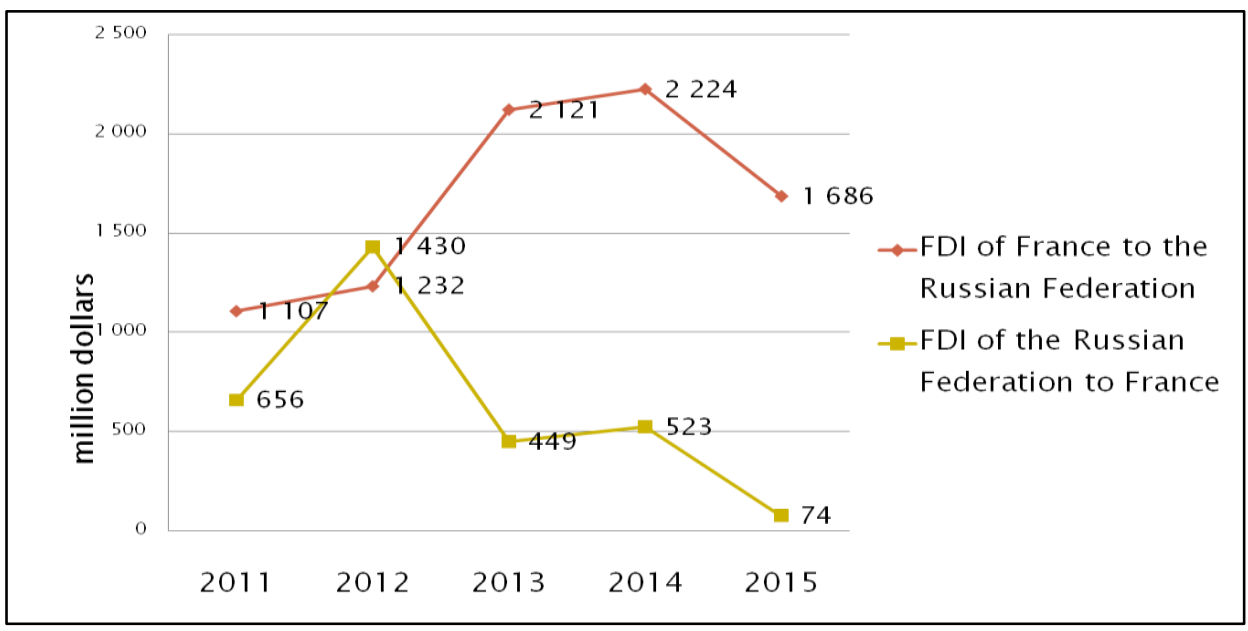

Fig 3. Mutual flows of foreign direct investment (FDI) in Russia and France (million US dollars) Source: Own results

Russian investments are directed to the sphere of tourism, agro-industrial complex, machine building, metallurgy, IT sector. However, sanctions, high taxes not typical for Russian business, competition of European companies limit the expansion of Russian investments in France.

The franchise companies work in various branches of the Russian economy, including power engineering, transport, aerospace, agro-industrial sector, and trade. The least affected were the French companies in the sphere of trade, the most affected was the automobile industry, where the sales fell by more than $40 \%$.

Renault shut down its Moscow car factory for several weeks in early 2015. Total lost its participation in the joint oil shale oil production project with Lukoil, long-term financing problems affected the Yamal LNG project, the purchase was frozen Shares of the second Russian gas producer Novatek. The largest French banks BNP Paribas and Société Générale - began to optimize their business in Russia (only Société Générale in 2014 reduced staff by 1500 people), the investment activity of these banks Almost ceased.

The entire unfavorable investment environment did not prevent cooperation in strategic sectors. Therefore, in the fall of 2015, Roskosmos signed another contract for launch services with the French telecommunications operator Eutelsat.

\section{Conclusions}

Trade sanctions seriously affect foreign trade and investment cooperation between Russian Federation and France. Both sides, Russian and French, suffer from the imposition of sanctions. These manifests itself in the following aspects: 
- a reduction in trade volumes, and as a result this led to a decrease in the role of the Russian Federation in France's foreign trade.

- a reduction of France's imports and exports of Russia, which necessitates the search for new trading partners for the marketing of their products.

- a sharp fall in mutual direct investment. French companies do not massively freeze the projects they started and do not get rid of their Russian assets. But with further degradation of existing conditions the investment sphere can also "roll back" a few years back.

- the decline in production in some industries.

- a reduction of budget revenues, due to the payment of less taxes.

The interdependence between Russia and France encourages countries to conduct a dialogue and seek the common solutions to existing problems. Also energy, finance and aircraft construction can be considered a perspective for Franco-Russian cooperation. Should not forget of the development of the investment climate. For example, in 2016, Russia took 40th place in the Doing Business rating, so many large enterprises of France view the Russian market as an opportunity for the growth of their national economy. In particular, the French company Schneider Electric actively acquires factories in Russia to localize production of its products and strengthen its presence in the Russian market. At the same time, by 2020 the company plans that Russia will become the third largest market for it. Thence, this illustrates the perspectives of the Russian-French trade and economic cooperation as a trade and mutual economic cooperation between two leaders.

\section{References}

Brodzicki T (2016) Does variety matter? Export pattern of Poland prior and after the accession to the EU. International Economics Letters 4(2):103-118. doi: 10.24984/iel.2016.4.2.5

Cieślik A, Michałek J, Mycielski J (2016) Globalization, international trade, and human development: a case of Central and Eastern Europe. Czech Journal of Social Sciences, Business and Economics 5(2):6-15. doi: 10.24984/cjssbe.2016.5.2.1

Crozet M, Hinz J (2016) Collateral Damage: The Impact of the Russia Sanctions on Sanctioning Countries' Exports. Research and Expertise on the World Economy, CEPII Working Paper, pp. 3-46

Danshina Y, Britchenko I (2017) Adaptation of domestic state governance to international governance models. Baltic Journal of Economic Studies 3(5):116-124. doi: 10.30525/2256-0742/2017-3-5-116-124

Dmitrieva NJ (2015) Economic Sanctions as a Political Pressure Instrument. Gosudarstvennoye upravleniye. Elektronnij Vestnik — Public administration. Electronic Herald 52:120-143.

Federal Customs Service of Russia (2018) Statistical Compendium. http://www.customs.ru Accessed 29 July 2018

Federal Service of State Statistics (2018) Statistical Compendium. http://www.gks.ru Accessed 28 July 2018

Gonda V (2013) Energetické záujmy Európskej únie a Ruska. Ekonomický časopis 3:297-322

Hafbaujer GC, Schott, Dzhej-Dzhej JKA, Oegg B (2007) Jekonomicheskie sankcii. Peresmotrennyj, 3-ie izdanie, Peterson Institut mezhdunarodnoj jekonomiki, Vashington, okrug Kolumbija, U.S.

Kastakova K (2016) Development of European Union and Russia trade in current situation: an analysis based on the index of trade complementarity. Trade policy 1:31-4

Kubeš V, Rančák J (2018) Sustainability of organization performance via management techniques. Entrepreneurship and Sustainability Issues 5(4):1031-1042. doi: 10.9770/jesi.2018.5.4(23)

Kuznetsov AV, Klinova MV, Kudryavtsev AK, Timofeev PP, France on the verge of change: economics and politics at the beginning of the 21 st century, $1^{\text {st }}$ edn. (Moscow: IMEMO RAS, 2016), $285 \mathrm{p}$.

Lisin E, Rogalev A, Strielkowski W, Komarov I (2015) Sustainable modernization of the Russian power utilities industry. Sustainability 7(9):11378-11400. doi: 10.3390/su70911378

Lisin E, Sobolev A, Strielkowski W, Garanin I (2016) Thermal efficiency of cogeneration units with multi-stage reheating for Russian municipal heating systems. Energies 9(4):269. doi: 10.3390/en9040269 
MakGi RW (2014) Dolzhny li my vvesti sankcii v otnoshenii Rossii iz-za Kryma? [Should we impose sanctions against Russia for the Crimea?] https://ssrn.com/abstract=2409997 HEAD=pobj Accessed 27 July 2018

Minchicova VS, Baryshnikov PY (2014) Sanctions 2014: will the investment flows between Russia and the leaders of the European Union decrease - by France and Germany. Young Scientist 17:304-310

Niño-Amézquita J, Dubrovsky V, Jankurová A (2017) Innovations and competitiveness in regional development: a comparison of Latin America, Europe, and China. Czech Journal of Social Sciences, Business and Economics 6(1):28-36. doi: 10.24984/cjssbe.2017.6.1.4

Ria News (2015) French business will invest several billion dollars into the Russian economy. http://ria.ru/economy/20150312/1052214509.html Accessed 27July 2018

Russell M (2016) Sanctions over Ukraine: Impact on Russia. Members' Research Service European Parliamentary Research Service, March, pp. 1-12

Sokolov M (2016) Pros and cons of anti-Russian sanctions. Political Russia is a social and political Internet magazine. http://politrussia.com/world/o-plyusakh-i-255/ Accessed 19 July 2018

The Central Bank of the Russian Federation (2018) Statistics. http://www.cbr.ru/statistics. Accessed 10 July 2018

United Nations (2018) Charter of the United Nations. http://www.un.org/en/sections/un-charter/chaptervii/index.html Accessed 20 Aug 2018

Zemguliene J, Valukonis M (2018) Structured literature review on business process performance analysis and evaluation. Entrepreneurship and Sustainability Issues 6(1):226-252. doi: 10.9770/jesi.2018.6.1(15) 